\title{
A Claim against Destiny as Criticism of Javanese Philosophy in Indonesian Novel
}

\author{
Andry Setiawan $^{1}$ and Joesana Tjahjani ${ }^{2}$ \\ \{andrysetiawan777@gmail.com ${ }^{1}$,tjahjani.joesana@gmail.com² \\ ${ }^{1,2}$ Faculty of Humanities, Universitas Indonesia, Depok. Indonesia
}

\begin{abstract}
The Javanese believe destiny as God's provision that must be obeyed. This article is a textual study that demonstrates how fate is claimed in a manner of textual criticizing the Javanese philosophy. We use a methodological foundation as the structural approach to the theory put forward by Tzevetan Todorov to examine aspects of the Fugitive Wisanggeni text narrative and the semiotic Roland Barthes to read the symbols present as marks in the text. The result of the study shows that the construction of Wisanggeni's character, as main character of the story, contradicts the concept of narima and rila in the Javanese philosophy. Meanwhile, from the results of semiotic analysis, it was found that, as a sign, narima carries an attitude that will lead to a simple life that does not impose personal will. The rila sign carries a meaning that people who submit to this attitude are of good morals. This is the sign of a person that he as individuals has the freedom to regulate his life.
\end{abstract}

Keywords: Javanese philosophy, destiny, symbol

\section{INTRODUCTION}

For a long time, the art of Purwa wayang has grown and developed in the archipelago. In the development, its function has changed, first with its function as a ceremonial tool that deals with the belief (religious magic), to a didactic educational tool, next regional art form, and finally a scientific object [1]. As time goes by, a lot of puppet stories were transformed. The transition, both in whole and in part, took place in various forms and media. In the spirit of popularity and contemporary, wayang stories were shifted into other forms, such as theater, dance, drama, film, song, and poetry. One of the most blooming elements of wayang story is the transformation of wayang stories into fictional forms. The emergence of wayang stories and their transformations in Indonesian fictional works is marked by the presence of a number of literary work, including Sri Sumarah (1975) by Umar Kayam, Nostalgia (1987) by Danarto, and Recognition of Pariyem (1981) by Linus Suryadi [2]. In addition, one of fictional stories resulting from changes in the elements of the wayang story is Wisanggeni Sang Buronan (2016) by Seno Gumira Ajidarmaor SGA.

In the introductory part of the latter novel, it is explained that the story of Wisanggeni Sang Buronan (thenceforth referred to as WSB), comes from a comic book the Birth of Bangbang Wisanggeni (1970) by RA Kosasih. WSB narrates the character of Wisanggeni, the son of 
Arjuna and an angel named Dewi Darsalana. Wisanggeni's presence was not expected by leader of the Gods because it is considered not in accordance with a predetermined destiny. Therefore, he was hunted by a messenger of Gods and became a fugitive. As an adult, Wisanggeni funeral came out of his place to find out his origin.

There are three other writings related to this article. Those are: Too Many Wisanggeni: Reinventing Wayang at the turn of the Century (2001) [3] by Marshall Clark, Wisanggeni: The Plaintiff of Self-Existence (2012) [4] by Nenden Rikma Dewi, and Wisanggeni the Fugitive A Pastiche Novel by Seno Gumira Ajidarma (A Study of Postmodernism) (2016) [5] by Trisna Gumilar. These three writings show a similarity, namely text analysis carried out or based on an understanding of a school of philosophy. In their article, Clark and Trisna used postmodernism to analyze Wisanggeni story, while Nenden used the existentialism theory.

Based on method of analysis, the works of Clark and Nenden have several things in common. Both use comparative studies in the analysis. Clark compared Wisanggeni figures in his two literary works, namely WSB and Saman of Ayu Utami. Meanwhile, Nenden compared WSB with Wisanggeni's version of Manabarata. Next, Trisna analyzes symptoms of postmodernism in WSB story elements, such as its characters and settings. However, from analysis results, Clark and Trisna found that WSB serves as an introduction to stories that were used for specific purposes. Clark stated that WSB is an effort of criticism against the New Order government. According to Trisna, WSB is an actualization of a story that holds the spirit and soul of present age, thus facilitating the re-reading of a piece of historical and interesting text in the present-day region that can be easily consumed by anyone. As for Nenden, she analyzed two Wisanggeni texts, and came with a finding that WSB story was the same as the story of Mahabarata which and still struggling with the same issue, namely self-existence.

In the WSB, the element of destiny often appears and becomes the focus of the story. The existence of destiny element becomes important because it becomes the center of the story. WSB is also thick with Javanese culture. This is indicated by the names of the characters, the setting of the place, and the name of the style or role that is part of Javanese wayang world. Therefore, it is interesting to see the relationship of destiny with Javanese culture which is rich in philosophy in WSB. This article aspires to see how a claim against destiny serves as a criticism towards Javanese philosophy. In addition, WSB has a number of important signs to be interpreted in order to get the results of an analysis an important as a whole.

\section{METHOD}

This article uses qualitative method. It is descriptive and tends to use analysis. The process and meaning are highlighted in a research using this method. This article uses a structural approach. A structural approach expressed by structuralism. The structuralism considers that literary texts built by various elements that form a totality. Elements in the structure do not have own function or meaning apart from others, the meaning/significance is determined by its relationship with other elements as a whole [6].

This article uses narratology theory as an opening analysis. In general, the narrative analyzes the structure of the narrative and analyzes the function of each element for the totality. One of the experts who studied narratology was Tzvetan Todorov. Todorov put forward three aspects in his research of narrative text, namely syntactic, semantic, and verbal aspects. The structure theory of Todorov's story was developed from the theory of Vladimir Propp's functions. Todorov simplifies the basic motives of Propp into a series of simple sentences, according to a logical understanding of the term [7]. Therefore, Todorov suggested that Propp function is not the smallest element in a story, but the structure of the story is the story sentence. 
Another theory used in this article is Roland Barthes's semiotics. As a follower of the Saussurean school, Barthes developed a theory of significance sign, signifiant-signifie. The main concept of Barthes' semiotic theory is myth. Myth is a type of speech; everything can be a myth if presented by a discourse [8]. Barthes developed the signifiant term to be E (expression), the signifie $\mathrm{C}$ term (content), and between $\mathrm{E}$ and $\mathrm{C}$ there is a relationship called $\mathrm{R}$ (relation). Each sign has two multilevel systems; the first system is called Barthes with a primary system (denotation), while the second development system of meaning is called a secondary system, which is further divided into "meta-language" and "connotation". The secondary development system that leads to $\mathrm{E}$ is called meta-language; this development raises the symptoms of language in the form of "synonymy". Meanwhile, the secondary development system that leads to $\mathrm{C}$ is called "connotation", and this becomes a myth.

\section{RESULT AND DISCUSSION}

\subsection{Relationship between Nature and Spirituality with Interpretation of Destiny}

Based on the observations on the sequence of events, we found that WSB sequences showed resistance against destiny of Gods in an attempt to criticize its own circle. Critics of Batara Guru Leadership were launched by a number of Gods who favored Wisanggeni. A number of figures who supported Wisanggeni were Arjuna, Dewi Darsalana, Hanuman, Sri Kresna, Batara Brahma, Sanghyang Antaboga, and Batara Baruna. A group consisting of humans, half humans, and Gods negates the view of destiny made by Guru Batara. The presumption is demonstrated by Sri Kresna's statement which states that Wisanggeni has a greater destiny, namely a symbol of rebellion which serves as an effort to correct Batara Guru Leadership who is considered to have exceeded his limits.

Meanwhile, Batara Guru and Batara Narada considered Wisanggeni has surpassed his destiny and therefore must be killed because his existence was unexpected and deviated from the plan. Batara Guru and his followers assume that fate is permanent. Everything that has been written down must be realized even though it uses the path of violence in the process. All that is written in fate is fixed. Matters that are not in accordance with destiny are considered deviations. Like deviation, there is an effort to return it to the right path.

There are two different interpretations of Wisanggeni's destiny. The first interpretation assumes that Wisanggeni is beyond his destiny, while other believes that Wisanggeni has a destiny as a person in charge of correcting the Batara Guru Leadership. This interpretation divides the character of the story into two interpretations. Both carry out characters' actions in accordance with their respective interpretations. One interpretation seeks to protect and help Wisanggeni while other seeks to destroy Wisanggeni so that life would go according to the written fate.

The two different interpretations of the characters in the story can be filtered based on the figures' nature and spirituality. The nature and spirituality of WSB figure was indeed associated with the background residence or location in which these figures live. Based on description of WSB scene, the place for the leaders was divided into heaven and earth. Batara Guru and Batara Narada live in heaven. Meanwhile, figures such as Sanghyang Antaboga, Hanuman, and Arjuna live in their respective places which are places for retreat and exile.

Based on background description in the text, kahyangan is a place difficult to reach; it is supernatural, not everybody can enter kahyangan, and it is difficult to find, hence it has high and further meaning. Kahyangan is interpreted as a palace that contains everything beautiful and pleasant. Therefore it serves an effect to complacent. Complacent is the basis for an emergence of mistakes and forgetting. In contrast to heaven, austerity and exile are usually filled 
with things that are unpleasant but function as a way to produce clear thinking and are able to know the difference between right and wrong. Based on this explanation, an overview can be drawn that the thought of interpretation of Wisanggeni's destiny relates to nature and spirituality in the background of his character. People who live in heaven tend to have an interpretation that Wisanggeni is outside of his destiny. Meanwhile, the figures residing on earth (non-heaven) interprets that Wisanggeni has far greater destiny.

\subsection{Questioning the Concept of Narima and Rila}

Within Javanese culture, the concept of accepting destiny is called narima and rila. Narima means being satisfied with one's fate, not rebelling, accepting with gratitude [9]. Narima is accepting everything in Javanese life, both material and liability. Thus, narima means accepting a reality and carrying out obligations.

In Koentjaraningrat, Kodiran mentions that the attitude of narima means surrendering to destiny [10]. According to Kodiran, the Javanese believe that man's life in this world is regulated in the universe, therefore it can be understood that surrendering to destiny means entrusting it to the rules that exist in the universe. This view causes the Javanese, both onto themselves, their own lives, and own minds to assume that all have entered into the totality of the universe. Thus, when the universe experiences difficulties, the Javanese feel the same. A view on the concept of narima in Javanese culture can be understood as a sign that has meaning. Analysis of the meaning of rila signs is presented in the chart below.

\begin{tabular}{|c|c|c|c|}
\hline $\begin{array}{l}\text { Signifier } 1 \\
\text { Narima }\end{array}$ & \begin{tabular}{|c|} 
Signified l \\
Content with one's fate, no rebelling, and \\
acknowledging with a sense of acceptance
\end{tabular} & & \\
\hline & $=$ Signifier 2 & Signified 2 & \\
\hline Attitudes that represe & f sufficient, submissive, and gratefulness & $\begin{array}{l}\text { Attitude that makes people live it self-aware, } \\
\text { obedient, and understand how to return the favor }\end{array}$ & \\
\hline \multicolumn{3}{|c|}{ Sign $2=$ Signifier 3} & Signified 3 \\
\hline \multicolumn{3}{|c|}{ The attitude of introspective signed with the desire to restore what God gives by obeying His decree } & $\begin{array}{l}\text { Produce an attitude that understands } \\
\text { limitation, not simple and earthy }\end{array}$ \\
\hline \multicolumn{4}{|c|}{ Sign 3} \\
\hline
\end{tabular}

At the level of first meaning (sign 1) or denotation, the sign of narima is interpreted as an attitude that represents a sense of enough, obedience, and gratitude. In the second layer of meaning (sign 2) or connotation, the meaning develops into an attitude that makes a person who embraces it wants to restore all things the God has given him by obeying all His provisions. As for the third level of meaning (sign 3) or myth, the sign of narima will lead to a simple life that does not impose on personal will, especially if it is contrary to God's provisions.

R. Soenarto Mertowardojo in Sasangka Djati through De Jong said that in fact what is called rila is sincerity of heart with a sense of happiness in terms of giving up all one's possessions, rights, and all fruits of one's work to God, sincerely and genuinely, because all is in the power of God, hence there must be nothing left in the heart. De Jong also said that praying to ask for something or hoping to avoid sorrow is something that has no meaning. Man must give all his desires and surrender without the slightest will to the Almighty.

Meanwhile, according to Magnis, rila attitude the ability to let go, as a willingness to give up personal right, ability and the results of one's own work if that is the responsibility or fate [11]. Same goes with Soenarto, according to Magnis, rila holds the concept of handing all that is within themselves to God without any sense of loss in one's heart. To complete the analysis of rila, a semiotic analysis of rila is carried out as a sign. This analysis is presented in the chart below. 


\begin{tabular}{|c|c|c|c|}
\hline $\begin{array}{l}\text { Signifier } 1 \\
\quad \text { Rila }\end{array}$ & \begin{tabular}{|c|} 
Signified l \\
Willingly to give up everything because one \\
believes that everything is in the power of God
\end{tabular} & & \\
\hline \multicolumn{2}{|c|}{$\begin{array}{r}\text { Sign 1 = Signifier 2 } \\
\text { Man's sincere attitude towards what he } \\
\text { because he was sure everything v }\end{array}$} & $\begin{array}{l}\text { Signified 2 } \\
\text { No strings attached or asking for compensation } \\
\text { for what was given because it was only } \\
\text { considered to have the back of God }\end{array}$ & \\
\hline \multicolumn{2}{|c|}{ Sign $2=$ Signifier 3} & Not having the will or purpose, other than simply surrendering to God & $\begin{array}{c}\text { Signified } 3 \\
\text { Earnest and has a clean conscience }\end{array}$ \\
\hline \multicolumn{4}{|c|}{$\begin{array}{c}\text { Sign } 3 \\
\text { A person with this attitude has good moral }\end{array}$} \\
\hline
\end{tabular}

At the first level (sign 1), the sign or denotation of rila means a sincere attitude to the things one gives to God because he believes everything is His. At the second level of meaning (sign 2) or connotation, sincere and selfless nature on the sign of rila offers a meaning that the sign produces thoughts that do not have a certain will, other than just surrendering to God. At the third level of meaning (sign 3) or myth, it seems that man with crazy attitude has good moral.

Based on the two meanings on the concept of narima and rila, we could draw a common thread, that is, both concepts will make a person who embraces it has good individual character without imposing his will personally. The person will embrace what God has given him as an expression of gratitude without imposing his personal desires. All things given by God becomes a gift that must be accepted sincerely.

In WSB, man also holds a big contribution in the storytelling. The resistance to destiny was initiated by Arjuna who felt hurt by the provisions made by Batara Guru. Man has its own sovereignty to fight Gods. This resistance was exploited by a number of other Gods to reprimands or corrects God's leadership. It can be summarized that in criticism towards Gods through resistance against his destiny, Arjuna served as a trigger to criticism, while Wisanggeni served as an intermediary or medium of criticism.

Therefore, the semiotic analysis of man as a sign is important because it sees its role in the story. As a trigger and intermediary, man has an important and crucial role in the process of WSB story. Without the presence of man, for example, if criticism occurs from God to God, the resistance to power appeared does not show a contrast of strength. Meanwhile, the semiotic analysis of man signs is represented in the chart below.

\begin{tabular}{|c|c|c|c|}
\hline $\begin{array}{l}\text { Signifier } 1 \\
\text { Human }\end{array}$ & $\begin{array}{c}\text { Signified } 1 \\
\text { Creature with sense of mind }\end{array}$ & & \\
\hline \multicolumn{2}{|c|}{ Man has a sense of mind to consider and decide something } & $\begin{array}{c}\text { Signified 2 } \\
\begin{array}{c}\text { Man has the right to carry out or take action } \\
\text { in accordance with his mind }\end{array}\end{array}$ & \\
\hline \multicolumn{3}{|c|}{ Sign 2 = Signifier 3} & $\begin{array}{c}\text { Signified } 3 \\
\text { Man has the right to determine his life }\end{array}$ \\
\hline \multicolumn{4}{|c|}{$\begin{array}{c}\text { Sign } 3=\text { Signifier } 4 \\
\text { Man sets his own life }\end{array}$} \\
\hline
\end{tabular}

At the first level (sign 1) or denotation shows that man has the reason to consider and decide something. At the second level of meaning (sign 2) or connotation, shows that man can think. The third level of meaning (sign 3) or myth results in the meaning of a sign that man regulates his own life. Nothing regulates man's life, other than himself.

In relation to destiny, based on the meaning of this sign, it appears that man is released from God's decree. Man has the nature of independence to take care of his personal affair as a result of reason. The analysis of man sign shows the way in which WSB is narrated. After carrying 
out his demands to Batara Guru, Wisanggeni also thought of his existence in the universe. He met Sri Kresna who advised him to live a destiny to disappear from the ongoing role.

Hence, Wisanggeni lived his destiny to disappear from the play of wayang world. However, Wisanggeni was not moksa (free from the world) or dead, but is out of wayang world. He is present in the real world as a madman who suddenly appears in the middle of a wayang show. Wayang show is playing Wisanggeni when the act after Wisanggeni is declared moksa or dead. Wisanggeni laughed at his own story, as if stating that it was not an authentic story of his life.

Wisanggeni's actions showed that Wisanggeni resisted fate. Wisanggeni did not live his destiny to perish. He fought out of the wayang world, which meant that he was also out of the power of Gods in it. Gods in the wayang world have no influence in the real world. Even though in the real world Wisanggeni must also be eliminated because it disrupts the ongoing establishment.

In addition to WSB, Wisanggeni's story was first present in the comic of Bambang Wisanggeni's birth and Mahabarata play of carangan story. Under Mahabarata version, Wisanggeni was the son of Arjuna who was married to Batari Dresalana, daughter of Batara Brama. His presence was not desired by the Gods because he was considered to have violated his fate. Wisanggeni is described as a figure whose strength exceeds that of the Pandavas. When he spoke, Wisanggeni did not use kromo (high language, Javanese) language to anyone, except Sanghyang Wenang. At the end of the story, Wisanggeni must die for the victory of Pandavas in Baratayuda war.

In the comic version, Wisanggeni story is not much of a different version than the Mahabharata as spin of wayang shown still a part of the story b he admits. However, in the final comic, Wisanggeni's fate is not clearly described. After demanding justice for Batara Guru, Wisanggeni was only described as having just woken up from his sleep after his body came out shadowing Sanghyang Wenang. The depiction of Wisanggeni was described as a wayang prototype character, dressed as Makuto, arm ring, and sumping. So even with other characters [12] [13].

In WSB, instead of demigod, Wisanggeni is described as a beggar. In addition, unlike the previous story, instead of looking arrogant and fierce, Wisanggeni looks cheerful. This is indicated by the sky dance he did when his was happy. Based on this, it appears that although using elements of wayang in WSB embodiment elements, the story is not the same as wayang story. Overall the separation of WSB is unlike those of wayang epics in general.

\section{CONCLUSION}

Based on a structural analysis of background relationships and figures, we find that the concept of interpretation of Wisanggeni destiny was related to nature and spirituality of the figures. A number of characters living in heaven tend to have the interpretation that Wisanggeni is outside of his destiny. Kahyangan is a place where they feel they have a higher position than man, so they feel they can regulate man's life. Heaven also has the effect of neglecting the position and place, thus making its residents unable to distinguish right from wrong. Meanwhile, the characters portrayed in a non-heavenly setting have the interpretation that Wisanggeni has a much greater destiny. Non-cultural backgrounds provide an understanding regarding the concepts of right and wrong with a number of these characters. They can see something there is something wrong with the Batara Guru Leadership, who then provides the support to Wisanggeni to make the corrections. 
Meanwhile, looking from a semiotic analysis, we found that the conclusions under WSB narrative showed that the story of Wisanggeni character in WSB was contrary to the concept of narima and rila in Javanese philosophy. This article shows that man has a choice in his destiny, either to accept and reject it. Man is individual with the freedom to determine his own lives. Not only accepting sincerely, but one may need to question his fate too.

\section{REFERENCES}

[1] Mulyono Sri 1989 Wayang: Asal-usul, Filsafat, dan Masa Depannya (Jakarta: CV Haji Masagung) p 2-34

[2] Nurgiyantoro Burhan 2003 Wayang dalam Fiksi Indonesia (Humaniora Volume 15) p 114

[3] Clark Marshall 2004 Too Many Wisanggeni: Reinventing the Wayang at the Turn of the Century. (Indonesia and the Malay World Volume 32) p 64-79

[4] Dewi Nenden Rikma 2012 Wisanggeni Sang Penggugat Eksistensi Diri (Apollo Project Volume 1 Nomor 1) p 40-47

[5] Gumilar Trisna 2016 Wisanggeni, Sang Buronan Sebuah Novel Pastische Karya Seno Gumira Ajidarma (Suatu Telaah Postmodernisme). Unpad Open Repostory www.repository.unpad.ac.id/8545/ diakses pada 10 November 2017

[6] Hawkes Terence 1978 Structuralism and Semiotic (London: Methuen Co, Ltd) p 17-18

[7] Todorov Tzvetan 1985 Tata Sastra (Jakarta: Djambatan) p 40

[8] Barthes Roland 2004 Mitologi (Yogyakarta: Kreasi Wacana) p 152

[9] De Jong S 1984 Salah satu Sikap Hidup Orang Jawa (Yogyakarta: Yayasan Kanisius) p 21

[10] Koentjaraningrat 1985 Manusia dan Kebudayaan Indonesia (Jakarta: Djambatan) p 340

[11] Suseno Franz Magnis 1984 Etika Jawa (Jakarta: PT Gramedia) p 143-144

[12] K. Saddhono and S. Supeni. "The role of dutch colonialism in the political life of Mataram dynasty: A case study of the manuscript of Babad Tanah Jawi." Asian Soc. Sci. vol. 10 no. 15 pp. 1-7, 2014

[13] K. Saddhono, "Language and superdiversity: Indonesians knowledging at home and abroad. By Zane Goebel." Soc. Stu. vol. 12 no.1 pp. 113-118, 2018 